\title{
Rohana Kuddus: Gender Dan Gerakan Sosial-Politik
}

\author{
Soraya Oktarina, Heru Permana Putra \\ IAIN Bukittinggi \\ Jln. Gurun Aua, Sumatera Barat 26181 \\ E-mail : sorayaoktarin4@gmail.com
}

\begin{abstract}
Emancipation and Gender Equality became a hot issue in the 20s. Women are judged to be entitled to the same rights as men in education, politics, economics, and others. Rohanna Kuddus, a woman from Koto Gadang, West Sumatra, dedicates her life to improving women of origin. In the 19th century, Minangkabau women were still underprivileged and marginalized. Rohana Kuddus believes that women must make a move to change their condition. Various movements were pioneered by Rohanna Kudus, ranging from gender struggle movements to politics. Rohana Kuddus: Gender and Socio-Political Movements uses research methods to collect interview sources, books, journals, and data from the internet that discusses Ruhana Kuddus. The limit of this paper is to look at the movements of Rohanna Kuddus in achieving gender equality and the various political movements that are running.
\end{abstract}

Keywords: Rohanna Kudus, Gender, Gender Equality, Women

\section{Pendahuluan}

Bangsa Indonesia lahir dari perjuangan para pemuda. Perjuangan yang tak hanya dilakukan oleh kaum pria, namun juga wanita. Di abad ke 19, sederet nama wanita turut menghiasi gerakan-gerakan kemerdekaan, seperti RA Kartini, Rohanna Kuddus, Tjut Nyak Dien, Tjut Mutia, Dewi Sartika, Martha Christina Tiahahu, Walanda Maramis, Nyai Ahmad Dahlan, Nyi Ageng Serang, Rahmah elJunusiyah dan Rasuna Said ${ }^{1}$. Namun faktanya, dalam cetakan sejarah kebangsaan, nama-nama perempuan ini justru tenggelam dibanding nama para tokoh pria. Tidak semua nama dari para pejuang wanita ini terkenang dan mendapatkan penghargaan dari negara sebagai tokoh nasional.

Faktanya, perjuangan kaum perempuan dalam perjalanan sejarah ternyata tidak pernah berhenti. Perempuan selalu melakukan gerakan-gerakan yang sangat signifikan terhadap pemberdayaan diri dan kesejahteraan kaumnya. Dalam pandangan gerakan feminsime liberal memandang ketidakadilan dalam relasi antara laki-laki dan perempuan itu pasti, dimana posisi laki-laki lebih diuntungkan. Untuk itu, agar perempuan pun memperoleh keuntungan, ia mesti terlibat dalam peluang dan kesempatan kerja serta pendidikan yang tersedia di ranah publik. Untuk mendapatkan kesetaraan, perempuan harus memberdayakan diri dan membuat sebuah pergerakan- pergerakan untuk kepentingan dan kesejahteraan kelompoknya sendiri ${ }^{2}$.

\footnotetext{
${ }^{1}$ Asvi Warman Adam, Pahlawan Nasional Perempuan (Sejarahwan Lembaga Ilmu Pengetahuan: Koran Tempo), Senin 7 November 2011.hlm.11

${ }^{2}$ Budi Rajab. Perempuan Dalam Modernisme Dan Postmodernisme. Jurusan Antropologi, Fakultas Ilmu Sosial dan Ilmu Politik, Universitas Padjadjaran, hal.6
} 
Sumatera Barat, sebagai daerah yang menjunjung tinggi perempuan dengan konsep matrilinealnya, memiliki sejumlah pergerakan-pergerakan yang dipimpin oleh kaum perempuan itu sendiri sejak sebelum kemerdekaan. Salah satu tokoh pergerakan perempuan Sumatera Barat, ialah Rohanna Kuddus. Rohanna Kuddus, tokoh perempuan asal Minangkabau yang akhirnya disetujui untuk di nobatkan menjadi tokoh nasional. Penobatan tersebut diberikan pada tahun 2019 di era kepemimpinan Presiden Joko Widodo berdasarkan putusan pertemuan antara Dewan Gelar, Tanda Jasa dan Tanda Kehormatan, dengan Presiden Joko Widodo. Sebelumnya, nama Rohana Kudus dimasukkan sebagai calon pahlawan yang tertuang dalam Surat Menteri Sosial Rl nomor: 23/MS/A/09/2019 tanggal 9 September 2019 perihal Usulan Calon Pahlawan Nasional Tahun 2019. Penobatan Rohanna Kuddus menjadi tokoh nasional tidaklah didapat dengan mudah. Usulan tersebut baru di setujui pada usulan ketiga, dimana dua usulan sebelumnya sempat mengalami penolakan. Secara formal, usulan diajukan pada Maret 2018.

Pengusulan Rohanna Kuddus sebagai tokoh nasional asal Sumatera Barat tentu bukan tanpa alasan yang kuat. Rohanna Kuddus sepanjang hidupnya memiliki catatan kiprah sejarah yang panjang dalam memperjuangkan nasib kaum perempuan. Rohana Kudus merupakan perempuan Minangkabau yang memcoba membuka pikiran tentang pembebasan perempuan dari ketidaksetaraan gender. Pergerakan-pergerakan yang dilakukan Rohana Kudus menjadi simbol manifestasi perjuangan kaum perempuan dari realita akan ketidak-seimbangan dunia memandang perempuan. Prinsip penting bagi Rohanna Kuddus, bahwasanya perempuan itu harus memiliki daya, perempuan harus memiliki keterampilan, perempuan harus memiliki modal sosial yang sama dengan kaum pria. Perempuan di mata Rohanna Kudus berhak menikmati akses pendidikan, kesehatan, ekonomi hingga layanan publik lainnya seperti yang biasanya kaum pria dapatkan.

Pada abad ke 19, kebebasan dan taraf kesejahteraan kehidupan perempuan Minangkabau sangatlah jauh berbeda dengan masa sekarang. Perempuan masih berada dipusaran praktek patriarki yang teraplikasikan melalui tatanan politik, ekonomi dan pendidikan. Stigma masyarakat tentang perempuan masih saja sebagai pekerja domestik yakni sumur, kasur dan dapur. Di Minangkabau, yang menganggung-agungkan paham kematrilinealanya, keadaan perempuan tak jauh ubahnya dengan daerah lain. Pengaruh kolonialisme dan patriakisme menciptakan kesenjangan bagi hak-hak perempuan, belum lagi praktek adat istiadat dan ajaran nenek moyang Minangkabau yang mengharuskan mereka untuk mengabdi di dalam lingkungan domestik. Perempuan seakan dianggap hanya sebagai pengurus rumah tangga dan menjaga anak-anak saja.

Pada masa kolonial, akses pendidikan hanya ramah terhadap laki-laki, artinya hanya kaum laki-laki saja yang mendapat kesempatan untuk bersekolah. Rohanna Kuddus, yang sejatinya berasal dari keluarga menengah ke atas, tetap tak mendapatkan akses untuk menikmati bangku sekolah. Alasannya, hanya karena Rohanna adalah seorang wanita. Rohanna Kuddus terlahir dari pasangan Muhammad Rasyad Maraja Sutan dan Kiam, beprofesi sebagai jurnalis sekaligus jaksa kepala. Rohana Kudus juga merupakan saudara sebapak dengan Sutan Syahrir.

Meski tak pernah mengenyam bangku sekolah, namun Rohanna Kecil adalah sosok perempuan yang sangat cerdas dan pantang menyerah. Rohanna adalah anak yang gemar mencari dan memiliki rasa keingintahuan yang tinggi. Rohanna tidak segan bertanya atau belajar dengan siapapun orang yang ditemuinya. Beruntung rohanna dikelilingi orang- orang pintar dan memiliki fasilitas bacaan yang lengkap. Dari ayahnya, Rohanna diajarkan baca 
tulis. Mohammad Rasjad Maharadja, ayah kandung Rohanna yang juga merupakan sosok pencetus Sekolah Rakyat khusus bagi pribumi di Koto Gadang. Sang ayah gemar membawakan majalah- majalah berbahasa Belanda untuk dibaca oleh putrinya.

Kesempatan membaca tak hanya ingin di nikmati oleh Rohanna sendiri, Rohanna yang sudah lancar baca tulis berkat didikan sang ayah berkeinginan agar seluruh temantemannya pun bisa memperoleh kesempatan yang sama dengan dirinya. Maka muncullah gerakan dari dalam diri Rohanna untuk mentransfer apa yang ia miliki kepada teman-teman sebayanya. Setiap pagi hari Rohanna mengajak anak anak seusianya yang belum bisa membaca untuk main kerumahnya. Di serambi depan rumahnya, Rohanna kecil mulai membacakan majalah dan buku buku yang ada sambil melatih teman sebayanya untuk mengeja hingga mereka pandai membaca. Tak hanya bahasa Belanda, namun semua kemampuan yang ia miliki, bahasa arab, baca tulis Al-quran, hingga keterampilan masakmemasak. Kegiatan menjadi seorang guru kecil Rohanna dilakukan dengan kondisi yang amat sederhana, belum mempunyai bangku dan meja, tetapi semuanya disuruh duduk bersila, dan Rohanna tak memungut imbalan sedikitpun ${ }^{3}$.

Perjalanan hidup sang ayah, ternyata memberikan dampak dan kontribusi yang sangat besar bagi Rohanna. Saat Rohanna mengikuti ayahnya di Alahan Panjang, ia pun bertetangga dengan istri pejabat Belanda atasan ayahnya, yang bernama Adiesa. Adiesa mengajarkan Rohana kepandaian menyulam, menjahit, merenda, dan merajut yang merupakan keahlian perempuan Belanda. Bersama Adiesa, Rohanna pun kerap belajar dan membaca berbagai berita politik, gaya hidup, dan pendidikan di Eropa, yang membuat pola pikir Rohanna semakin lebih terbuka dan modern. Sebenarnya untuk keterampilan jahit menjahit, Rohanna telah lebih dahulu diajarkan oleh neneknya Sini Tarmini, pembuat renda terawang Bukittinggi yang terkenal ${ }^{4}$.

Mengikuti tugas sang ayah, Rohanna sempat hidup berpindah-pindah. Dimanapun ia berada, ia selalu menjadi inspirator dan penggerak anak-anak seusianya untuk pandai membaca. Berbekal ilmu dan keterampilan yang ia punya, ia tak pernah bosan dan mengeluh untuk mengajar. Tak heran, diantara anak seusianya, Rohanna sangat disenangi dan terkenal ditengah masyarakat berkat jasanya ${ }^{5}$.

Di tahun 1897, Rohanna kembali memutuskan untuk menetap di Koto Gadang, wafatnya sang ibu dan keputusan ayahnya untuk menikah lagi dengan Asiah dan Rabiah anak jaksa di Bonjol yang berasal dari Natal, membuat Rohanna mantap memutuskan untuk hidup mandiri dan menetap di Koto Gadang kampung halamannya. Pada saat itu Koto Gadang masih berada dalam kondisi yang terpinggirkan, rawan mengalami kekerasan, baik seksual, ekonomi, fisik maupun psikis. Perempuan Koto Gadang masih saja dipingit, tidak boleh bersekolah, harus melayani suami. Nagari Koto Gadang dikenal sangat kuat menjalankan adat dan budaya Minangkabau. Hal itu tercemin dari ketatnya mereka menganut sistem matriachat (garis keturunan ibu). Kekuasaan dan keputusan tidak lah berada di kaum perempuan, perempuan hanya sebagai simbol penjaga, akan tetapi kekuasaan sebagai pemimpin dalam kaum tetap berada pada laki-laki ${ }^{6}$.

Berdasarkan kondisi inilah, Rohanna merasa perlu melakukan perubahan untuk nasib perempuan di kampung halamannya. Rohanna berpikir perempuan harus bangkit dari ketertinggalannya selama ini. Dalam tulisannya, Rohanna pernah berkata:

\footnotetext{
${ }^{3}$ Djaja, Tamar, Rohana Kudus Srikandi Indonesia Riwayat Hidup dan Perjuangannya, cetakan ke sepuluh, (Jakarta :

Mutiara : 1980), hlm 29.

${ }^{4}$ Ibid, hal 27

${ }^{5}$ Ibid, hal 29.

${ }^{6}$ Mengenai kuatnya masyarakat dalam rnenjalankan adapt ini banyak diceritakan dalam berita-berita di Soeara Kota Gedang. 5 Oktober 1920, Soeara Kota Gedang 17 Desember 1920, dan Soeara Kota Gedang 1921.
} 
"Perputaran zaman tidak akan pernah membuat perempuan menyamai laki-laki. Perempuan tetaplah perempuan dengan segala kemampuan dan kewajibannya. Yang harus berubah adalah perempuan harus mendapat pendidikan dan perlakuan yang lebih baik. Perempuan harus sehat jasmani dan rohani, berakhlak dan berbudi pekerti luhur, taat beribadah yang kesemuanya hanya akan terpenuhi dengan mempunyai ilmu pengetahuan." ${ }^{7}$

Dari tulisan dan pola pikirnya, Rohanna mencoba menawarkan konsep kesetaraan gender dengan tidak menuntut persamaan hak perempuan dengan laki-laki. Namun lebih pada fungsi dan karakter alamiah dari perempuan sesuai dengan kodrat yang melekat pada dirinya. Perempuan sejati adalah perempuan yang berdaya, untuk itu dibutuhkan ilmu pengetahuan dan keterampilan, dan juga pendidikan untuk kelompok perempuan itu sendiri dalam menjalankan hidupnya ${ }^{8}$.

Ema Pratama Agustiningsih dalam tulisannya tentang Pergerakan Perempuan Di Minangkabau: Kiprah Rohana Kudus Dalam Nasionalisme Tahun 1912-1972 melontarkan Gerakan yang dilakukan oleh Rohanna kuddus lebih ditujukan untuk meberdayakan perempuan dan membantu perempuan Koto Gadang dari ketertinggalan. Rohanna Kuddus hadir sebagai pembawa perubahan dan memberikan daya bagi perempuan pada masanya untuk beranjak dari ketidaksetaraan. Pemberdayaan yang dilakukan oleh Rohana merupakan gerakan sosial dalam mendukung tercapainya sebuah kesetaraan gender.

Apa yang Rohanna kuddus lakukan, pun menjadi apa yang kelompok feminisme liberal upayakan. Gerakan sosial pemberdayan perempuan menjadi hal utama yang dapat dilakukan dalam mendukung kesetaraan gender. Gerakan Feminisme liberal memandang semua manusia laki-laki dan perempuan diciptakan seimbang dan serasi, semestinya tidak ada penindasan satu dengan yang lainnya, laki-laki dan perempuan sama-sama mempunyai kekhususan. Secara ontologis keduanya sama, hak-hak laki-laki dengan sendirinya juga menjadi hak-hak perempuan, perempuan dapat bekerja bersama laki-laki, perempuan diharapkan dapat terintegrasi secara total di dalam semua peran, termasuk bekerja di luar rumah ${ }^{9}$. Berbagai gerakan pemberdayaan perempuan diciptakan rohanna, mulai dari mendirikan Kerajinan Amai Setia (KAS), pendidikan pemberdayaan Roehana School, pemberdayaan ekonomi hingga menjadi pelopor jurnalis wanita pertama di Sumatera Barat dengan Soenting Melayunya.

Perjuangan yang dilakukan Rohanna tak hanya seputar perjuangan mencapai kesetaraan gender. Kiprah Rohanna tak hanya sebagai sebuah gerakan sosial melepaskan kaum perempuan dari kemarjinalan, namun Rohanna pun ikut bersumbangsih dalam gerakan politik Indonesia. Rohanna aktif membantu pergerakan-pergerakan politik yang terjadi saat itu. Rohanna memberikan ide, gagasan hingga kalimat yang mampu membakar semnagat para pemuda. Rohanna menjadi pelopor dalam terbentuknya dapur umum dan badan sosial bagi para gerilyawan di masa merebut kemerdekaan. Sementara itu, melalui tulisan-tulisannya, Rohanna aktif membuat artikel kritikan dan kontra terhadap penjajah. Rohanna dengan lugas menuliskan ketidaksukaannya akan praktik -praktik penjajah yang berlangsung didaerahnya. Penulisan di dalam surat kabar milik Rohanna kerap menampilkan isu isu seperti politik, ekonomi dan kriminal. Ia berharap dengan kritik dan isu yang ia tulis, mampu membuka pikiran dari keprimodialan yang selama ini terjadi. Bahkan Rohana sampai mendorong agar kaum perempuan untuk ikut terjun kedalam organisasi pergerakan dan percaturan politik ${ }^{10}$.

\footnotetext{
${ }^{7}$ Ibid.,

${ }^{8} \mathrm{https} / / /$ www.kenangan.com/biografi/roehana-koeddoes

${ }^{9}$ Nasaruddin Umar, Argumen Kesetaraan Gender perspektif Al- Qur'an, (Jakarta: Paramadina, 1999), hlm. 64

${ }^{10}$ Dahlia, fitriyanti. 2013. Roehana Koeddoes : Perempuan Menguak Dunia . Yayasan d'Nanti,. Jakarta .
} 


\section{TEORI}

\section{A. Kesetaraan Gender}

Gender dalam istilah berarti "seks" atau jenis kelamin. Di dalam Women's Studies Enclopedia, gender dijelaskan sebagai suatu konsep kultural yang berupaya memuat pembedaan dalam hal peran, perilaku, mentalitas, dan karakteristik emosional antara pria dan wanita yang berkembang dalam masyarakat ${ }^{11}$. Perbincangan mengenai gender mulai hangat dibicarakan memasuki abad 20. Gender menjadi topik yang tiada habisnya untuk dibahas. Topik diskursus paling menarik ketika berbicara mengenai konsep gender adalah tentang kesetaraan. Isu kesetaraan adalah menjadi isu yang sampai saat ini masih terus diperjuangkan dengan memiliki segudang pro dan kontra.

Gender pada dasarnya bukanlah apa yang didasarkan kepada jenis kelamin, namun gender adalah sesuatu yang terjadi dan terdapat pada laki laki dan perempuan. Gender berbeda dengan jenis kelamin. Jenis kelamin lebih condong terhadap fisik seseorang sedangkan gender lebih condong terhadap tingkah lakunya. Jenis kelamin merupakan status yang sudah tercipta atau bawaan dari lahir, sedangkan gender merupakan status yang diperoleh atau didapatkan. Gender tidak bersifat biologis, melainkan dikontruksikan secara sosial. gender dipelajari melalui sosialisasi dan gender dapat berubah. Istilah gender pertama sekali ditawarkan oleh Robert Hellen dalam Rasyidin, Konsep Gender diperkenalkan dengan memisahkan fitur manusia berdasarkan pada definisi sosial budaya dan manusia yang bertakrif pada karakteristik fisik biologis ${ }^{12}$.

Membahas konsep gender adalah upaya mencari apa yang dinamakan dengan kesataran gender. Kesetaraan gender erat hubungannya dengan keadilan. Terciptanya suatu keadilan antara laki-laki dan perempuan. Terciptanya suatu kesetaraan dan keadilan gender adalah wujud adri tidak tidak adanya perlakuan diskriminasi. Naomi dalam Free Hearty dan Djazlam Zainal mengatakan bahwa perempuan sebagai manusia biasa, individual, tidak lebih baik dan tidak lebih buruk dibanding laki-laki, dan perempuan mempunyai hak-hak yang setara dengan laki-laki. Kesadaran gender yang dikumandangkan bukan dengan tujuan

\footnotetext{
${ }^{11}$ Hellen Tierney (ed), Women's Studies Inclopedia, vol I, (New York: Green Word Press), hal 153

${ }^{12}$ Dr. H. Rasyidin. S.Sos.MA. 2014. Politik Gender Aceh : Studi tentang Pemberdayaan Politik Gender di Provinsi Aceh

Pasca MoU Helsinki. Lhokseumawe : Unimal Press, Hal. 24 - 27.
} 
untuk menginjak laki-laki, tetapi lebih kepada equality (kesetaraan) bukan kesamaan (sameness) ${ }^{13}$.

Riant Nugroho dalam Rasyidin menyatakan bahwa gender yaitu adanya kesamaan kondisi untuk laki-laki dan perempuan dalam memperoleh kesempatan dan hak-haknya sebagai manusia, agar mampu berperan dan berpartisipasi dalam kegiatan politik, hukum, ekonomi, sosial budaya, pendidikan dan kesehatan serta dalam menikmati hasil pembangunan. Terwujudnya kesetaraan dan keadilan gender ditandai dengan tidak ada lagi diskriminasi antara kaum perempuan dengan kaum laki-laki. Sehingga perempuan dan lakilaki berkemampuan yang sama untuk mengakses, berpeluang untuk berpartisipasi dalam pembangunan, memperoleh manfaat yang setara dan berkeadilan untuk menikmati hasil pembangunan tersebut ${ }^{14}$.

\section{B. Gerakan Sosial-Politik}

Gerakan Sosial-politik adalah bentuk gerakan keikutsertaan masyarakat dalam hal politik. Gerakan politik senada dengan gerakan sosial yang terjadi di dalam masyarakat, namun tujuan utamanya adalah untuk mempengaruhi atau mengubah suatu kondisi perpolitikan. menurut Widyanta, seara etimologi gerakan adalah aktivitas sosial berupa gerakan sejenis tindakan sekelompok yang merupakan kelompok informal yang berbentuk organsisasi, berjumlah besar atau individu yang secara spesifik berfokus pada suatu isu-isu sosial, budaya atau politik dengan melaksanakan, menolak atau mengkampanyekan sebuah perubahan sosial ${ }^{15}$.

Menurut Sidney Tarrow “Gerakan sosial merupakan politik perlawanan yang terjadi ketika rakyat biasa yang bergabung dengan para kelompok masyarakat yang lebih berpengaruh menggalang kekuatan untuk melawan para elit, pemegang otoritas, dan pihakpihak lawan lainnya”. Gerakan Sosial politik merupakan suatu bentuk ketidaksetujuan akan suatu kondisi, dan ingin mengubah kondisi yang terjadi pada saat ini

\footnotetext{
${ }^{13}$ Alfirahmi \& Retno Ekasari . Kontruksi Realitas Sosial Perempuan Tentang Gender Dalam Pembentukan Karakteristik Anak Terhadap Pemahaman Gender . Institut Ilmu Sosial dan Manajemen STIAMI

${ }^{14}$ Dr. Rasyidin, S.Sos.M.A dan Fidhia Aruni, S.I.Kom. Gender Dan Politik; Keterwakilan Perempuan Dalam Politik. Unimal Perss. hal.24

${ }^{15}$ AB Widyanta, Problem Modernitas Dalam Kerangka, Yogyakarta: Cinelaras Pustaka rakyat Cerdas, 2002, 12.
} 


\section{Metode Penelitian}

Penelitian adalah suatu kegiatan yang dilaksanakan dengan suatu sistematika metodologi ilmiah dengan tujuan untuk memperoleh sesuatu yang baru atau asli dalam usaha memecahkan suatu masalah yang setiap saat dapat timbul di masyarakat ${ }^{16}$. Didalam melakukan sebuah penelitian, diperlukan sebuah metode yang menjadi pisau dalam menggali, mencari, menganalisa hingga memaparkan sebuah penelitian. Adapun metode penelitian yang digunakan dalam tulisan ini adalah metode historis dengan melihat dan menelurusi kejadian-kejadian yang telah lampau. Kegiatan pengumpulan sumber dilakukan dengan melakukan studi pustaka terhadap buku-buku ataupun jurnal yang berkorelasi, meneliti dan menguji keabsahan sumber otentik pendukung lainnya, seperti surat kabar sunting melayu, melakukan wawancara dan diskursus dengan sejumlah tokoh sejarahawan. Metode penelitian sejarah dipilih bertujuan untuk mempelajari dan menggali fakta-fakta atau pengalaman dan perkembangan masa lampau dengan berusaha menarik kesimpulan dan mencoba membuat interpretasi terhadap data dari peristiwa tersebut ${ }^{17}$.

Adapun batas dan ruang lingkup dalam tulisan ini adalah melihat gerakan-gerakan yang dilakukan Rohanna Kuddus dalam mencapai kesetaraan gender di Minangkabau serta implikasi gerakan tersebut dalam menjadi sebuah gerakan politik. Melihat bagaimana Aksi gerakan Rohanna Kudus dalam mendobrak kemarjinalan dan keterbelakangan kondisi perempuan yang ada akibat cengkaraman patriarki dan kolinalisme.

\section{PEMBAHASAN}

\section{A. Rohanna Kuddus, Pejuang Kesetaraan Perempuan Di Minangkabau}

Rohanna Kuddus salah satu perempuan Sumatera Barat dengan penobatan gelar sebagai tokoh pahlawan nasional. Rohanna Kuddus perempuan yang memberikan inspirasi bagi perempuan lainnya untuk mencapai sebuah kesetaraan dan kebangkitan melawan ketimpangan dan praktek dominasi patriarki. Sesuai dengan apa yang dikemukakan Naomi

\footnotetext{
${ }^{16}$ Sukandarrumidi, Metodologi Penelitian: Petunjuk Praktis untuk Peneliti Pemula, Yogyakarta: Gajah Mada University Press, 2006., hlm. 111.

${ }^{17}$ Kusmayadi, et al., Metodologi Penelitian Dalam Bidang Kepariwisataan (Jakarta: Gramedia Pustaka Utama, 2000), hlm. 28-29. 13Louis Gottschalk, Mengerti Sejarah, terjemahan Nugroho Notosusanto (Jakarta: Universitas Indonesia Press, 1983), hlm. 32.
} 
dalam Free Hearty dan Djazlam Zainal yang mengatakan bahwa perempuan sebagai manusia biasa, individual, tidak lebih baik dan tidak lebih buruk dibanding laki-laki, dan perempuan mempunyai hak-hak yang setara dengan laki-laki, Rohanna pun mengklaim bahwa sampai kapanpun perempuan tidak akan bisa sama dengan laki laki. Perempuan tetaplah perempuan dengan segala kemampuan dan kewajibannya. Yang menjadi penting adalah bagaimana perempuan juga bisa mendapat pendidikan dan perlakuan sama, perempuan harus sehat jasmani dan rohani, berakhlak dan berbudi pekerti luhur, taat beribadah yang kesemuanya hanya akan terpenuhi dengan mempunyai ilmu pengetahuan.

Kondisi keterpinggiran dan keterbelakangan perempuan di dominasi oleh pengaruh stigma budaya yang mengatakan perempuan hanya diposisikan sebagai pekerja domestik. Kemarjinalan juga terjadi akibat pemberdayaan perempuan yang belum merata. Pemberdayaan ini sangat terkait dengan pendidikan, sebab keterbelakangan perempuan dominan disebabkan oleh rendahnya pendidikan yang dimiliki oleh kaum perempuan tersebut. Berdasarkan hal inilah, Rohanna menunjukan kepedulian dan perhatiannya terhadap nasib perempuan. Kegusaran hatinya akan ketiadaan kesempatan bagi perempuan memperoleh akses publik, membuatnya berfikir lanjut tentang apa langkah konkrit yang harus dilakukan. Ketidak-beruntungan kondisi perempuan di Minangkabau, harulah diakhiri dengan melakukan pergerakan untuk keluar dari ketertindasan tersebut, dan hanyalah kaum perempuan sendiri jua lah yang bisa melakukannya.

Rohanna yang terkenal pintar sedari kecil, melebihi rata rata anak seuisanya mengabdikan dirinya untuk mengajarkan berbagai pengetahuan dan keterampilan yang ia dapatkan terhadap perempuan lainnya. Aspek pendidikan adalah fokus dan langkah utama yang disasar rohhana untuk merubah kondisi perempuan minangkabau. Menurut Rohana Kuddus kemarjinalan perempuan harus melalui pendidikan, mencerdaskan pola pikir dan ekonomi perempuan.. Dengan pendidikan perempuan, Ruhana Kuddus berusaha melakukan sebuah pemberdayaan. Rohanna secara signifikan merubah mindset perempuan yang selama ini hanya mencari nafkah dengan ke sawah, berladang, berjualan, dan menjahit, untuk mulai belajar keahlian baca tulis. Pendidikan formal pada saat tersebut menjadi suatu yang terlupakan dan tabu bagi perempuan, sekolah bagi perempuan menjadi hal yang tidak penting. Stigma masyarakat hasil cengkraman patriarki ditambah budaya adat istiadat, membuat strereotip masyarakat menganggap perempuan tidak perlu diberdayakan melalui 
pendidikan formal. Akses perempuan cukup hanya terlibat pada area sumur, kasur dan dapur.

Sesuai dengan Rasyidin, menyatakan bahwa gender yaitu adanya kesamaan kondisi untuk laki-laki dan perempuan dalam memperoleh kesempatan dan hak-haknya sebagai manusia, agar mampu berperan dan berpartisipasi dalam kegiatan politik, hukum, ekonomi, sosial budaya, pendidikan dan kesehatan serta dalam menikmati hasil pembangunan. Dengan menjadikan perempuan sebagai kelompok yang terdidik, maka akan berpengaruh pada peningkatan partisipasi perempuan di bidang lainnya. Dengan demikian, kesenjangan yang terjadi antara laki-laki dan perempuan perlahan bisa terminimalisirkan.

Langkah konkrit pemberdayaan kepada perempuan, pada tanggal 11 februari 1911, Rohanna Kuddus mendirikan sekolah Kerajinan Amai setia (KAS). Kerajinan Amai Setia pada awalnya hanyalah sebagai tempat berkumpul dan bertemu perempuan- perempuan Koto Gadang. Kemudiaan, Rohanna mengarahkan Kerajinan Amai Setia tersebut menjadi sebuah lembaga pendidikan bagi perempuan, Rohana Kuddus bertindak langsung mejadi guru dalam mengajarkan perempuan menulis membaca dan berhitung. Tidak ada batas umur dan syarat tertentu bagi perempuan yang ingin belajar di KAS. KAS sendiri bertujuan memberikan pendidikan bagi anak-anak wanita dalam bidang Menulis membaca, Berhitung, Urusan Rumah Tangga, Agama, akhlak, Kepandaian tangan, Jahit menjahit, Gunting menggunting, Sulam-menyulam, Dan lain-lainnya ${ }^{18}$.

Keputusan pendirian KAS bukanlah sebuah perkara yang mudah. Mengajak perempuan untuk menempuh dan mengikuti pendidikan sama halnya dengan memberontak stuktur kontruksi paradigma pikiran masyarakat. Tak sedikit kendala yang harus dihadapi oleh Rohanna, baik dari kelompok laki-laki, pemuka adat, bahkan perempuan itu sendiri. Mereka beranggapan, untuk apa perempuan harus "menyerupai" lakilaki. Bagi kalangan perempuan Minangkabau saat itu, dirinya harus menerima kodrat bahwa perempuan hanya sebagai "partner" laki laki dalam kehidupan rumah tangga. Sementara kaum laki -laki sendiri menentang adanya keinginan perempuan untuk menuntut ilmu. Menurut laki-laki keputusan perempuan untuk menuntut ilmu akan mengurangi kemampuan dan waktunya untuk memasak dan mengerjakan pekerjaan rumah lainnya.

${ }^{18}$ Fitriyanti, op.cit. hlm. 39 
Perempuan akan lupa pada tugas dan fungsi dasarnya. Kaum laki laki mengatakan pendidikan formal bukanlah hal yang paling penting bagi perempuan, karena pada akhirnya tugas utama dan wajib bagi perempuan adalah di rumahnya, karena laki-laki sudah terlalu sibuk diluar rumah untuk mengurusi urusan pencarian nafkah.

Penolakan yang lebih besar berasal dari kalangan pemuka adat. Pemuka adat mengatakan adat istiadat minangkabau sudah mengistimewakan perempuan dengan sistem matrilinealnya. Perempuan sudah ditinggikan derajatnya dengan menjadi penjaga rumah gadang. Posisi perempuan sudah terhormat dan tidak membutuhkan pendidikan apa-apa lagi. Perempuan harus taat dan tunduk ke adat, sebagai bentuk moral dan berbudi. Perempuan Minangkabau yang berusia 12 tahun harus sudah rela dipingit dan dijodohkan dengan laki-laki pilhan sang mamak. Sehingga sebelum usia tersebut, perempuan harus fokus dididik untuk urusan pekerjaan rumah tangga, dan jika telah menikah harus total mengabdi unutk mengurusi urusan rumah tangga. Keberadaan sekolah ataupun pendidikan formal hanya dipandang sebagai bentuk pembodohan dan membuat perempuan menjadi keluar dari ajaran adat semestinya.

Banyaknya pertentangan dan kendala yang dialaminya, tak membuat Rohanna surut. Untuk menyampaikan niatnya dalam mendirikan sebuah lembaga pendidikan bagi permepuan, Rohanna harus melakukan sebuah pertemuan besar. Ia mengundang seluruh perempuan Koto Gadang. Di informasikan pertemuan tersebut dihadiri lebih dari 60 orang perempuan, dan empat orang laki-laki sebagai tokoh masyarakat Koto Gadang ${ }^{19}$. Dalam pertemuan tersebut Rohanna menyampaikan maksud dan cita citanya terhadap nasib perempuan di Koto Gadang.

"Khususnya bagi perempuan dari kalangan tidak mampu. Apabila perempuan bisa mencari nafkah untuk diri sendiri, paling tidak, kaum perempuan tidak akan bergantung pada orang lain. Hidup terus berjalan, masalah selalu ada. Kita tidak bisa diam dan hanya menangis," kata Rohana dalam pertemuan tersebut. ${ }^{20}$

\footnotetext{
${ }^{19}$ Etek, Azizah, Mursjid, A.M. \& Arfan, B.R.. (2007). “Koto Gadang Masa Kolonial”, Yogyakarta: LkiS.

${ }^{20} \mathrm{https} / /$ historia.id/kultur/articles/perjuangan-rohana-dalam-pendidikan-kaumnya-Pdle3/page/3
} 
Cita-cita dan maksud baik Rohanna di terima dengan baik oleh perempuan yang hadir dalam pertemuan tersebut. Namun pengakuan tersebut bukanlah langkah yang bisa langsung di wujudkan. Rohanna memaklumi, apa yang ia dengar pada saat pertemuan tersebut bisa saja berubah ketika perempuan tersebut kembali kerumah nya masing-masing. Oleh karena itu Rohanna mencoba mencari cara lain untuk mewujudkan misinya mendirikan sebuah lembaha pendidikan. Rohanna mencoba menemui para perantau Koto Gadang. Rohanna meminta dukungan dan kerjasama untuk merealisasikan upaya menghilangkan keterpinggirkan perempuan. Dan pada akhirnya, maksud baik rohanna bak gayung bersambut oleh seorang yang bernama Ratna Putri. Ratna adalah seorang istri jaksa di daerah kayu tanam. Bersama Ratnalah, Rohanna akhirnya bisa mendirikan sebuah sekolah yang bernama Kerajinan Amai Setia

Selain Sebagai Lembaga pendidikan, KAS juga menjadi sebuah ladang penyokong ekonomi bagi perempuan Koto Gadang. Kerajinan Amai Setia yang semula menjadi lembaga pendidikan bagi perempuan, kemudian berubah menjadi usaha dagang hasil produksi perempuan. Perkembangan luar biasa dari Kerajinan Amai Setia yaitu menjadi basis dan menjadi pusat kerajinan rumah tangga di Koto Gadang. Rohana kerap menjalin kerjasama dengan pemerintah Belanda untuk pemesanan peralatan dan kebutuhan jahit-menjahit. Rohana menjadi perantara dalam memasarkan hasil kerajinan muridnya ke Eropa. Bahkan sekolah Rohana menjadi sebuah lembaga perekenomian berbasis industri rumah tangga serta koperasi simpan pinjam dan jual beli yang anggotanya semua perempuan yang pertama di Minangkabau.

Pada awal berdiri, Kerajinan Amai Setia sudah memiliki anggota sebanyak 151 orang perempuan $^{21}$, dan jumlah ini terus bertambah setiap harinya. Tingginya antusias perempuan terhafap KAS, membuat KAS tidak hanya sebagai lembaga pendidikan biasa, namun KAS berbenah diri mulai menambah pelajaran pelajaran keekonomian, manajemen dan keuangan. Hal ini ditujukan agar perempuan mengerti dan memahami bagaimana cara mengatur pola keuangan yang terstruktur, bagaimana perempuan bisa merancang sistem keuangan yang terencana, sehingga bisa diaplikatifkan dalam kehidupan sehari hari. perempuan diharapkan lebih "melek" dalam kesejahteraan ekonomi baik untuk dirinya ataupun keluarganya. Jika perempuan sudah paham akan sistem manajerial keuangan,

${ }^{21}$ Zed, Mestika \& Chaniago, Hasril. (2018). "Riwayat Hidup dan Perjuangan Ruhana Kuddus Tokoh Perempuan yang Mendahului Zaman", Padang: UNP Press. 
pandai mencari uang, dan bisa mengatur pengeluaran dan pendapatan dengan baik, maka perempuan mampu mengejar ketertinggalannya dalam kesetaraan ekonomi. Kehadiran Kerajinan Amai Setia telah berhasil menumbuh-kembangkan perempuan mandiri dari segi ekonomi, sehingga perempuan bisa berdiri sendiri, perempuan bisa berkarya dan berdikari untuk memenuhi kebutuhannya sendiri. Perempuan tidak menjadi kelompok yang lemah dan terlalu bergantung dengan laki-laki. Kemandirian perempuan ini diharapkan dapat meminimalisir dan mengatasi kekekerasan terhadap perempuan yang saat itu lazim terjadi.

Selain Rohanna Kuddus, pembelajaran KAS juga dibantu oleh guru guru yang sudah sangat ahli dibidangnya, diantaranya Tuo Tarimin, Hadisan, Mahdaniar Mansur dan Tuo Sini. Keinginan Rohanna Kudus dalam mensejahterakan perempuan dalam bidang bidang ekonomi diakui dan diterima keberhasilannya Pemerintah Hindia Belanda. Pada tanggal 13 Januari 1915, KAS mendapat pengakuan resmi dari Pemerintah Hindia Belanda sebagai usaha berbadan hukum. Selain KAS, Pada tahun 1917 Rohanna juga mendirikan sekolah keterampilan perempuan bernama Roehana School di Bukittinggi

Selain Pendidikan dan ekonomi, perjuangan Rohanna dalam mencapai kesetaraan terhadap perempuan tak hanya berhenti sampai disitu saja. Rohanna yang suka menulis dan pintar membuat tulisan tulisan fenomenal, mencoba mendongkrang paradigma keterkukungan perempuan melalui artikel artikel. Rohanna kian menunjukan taringnya dengan menerbitkan "Soenting Melayoe". Rohanna yang sedari kecil akrab dengan berbagai majalah, surat kabar dan bacaan, terlatih dan gemar membacakan berita untuk orang-orang disekitarnya. Sunting melayu adalah surat kabar perempuan pertama yang diisaratkan Rohanna untuk melawan ketidakadilan bagi perempuan, memberikan edukasi-edukasi dan pembelajaran yang lebih luas kepada perempuan. Target Rohanna Kuddus disini, bukan lagi hanya semata untuk perempuan di Koto Gadang, namun untuk skala yang lebih luas lagi. Rohanna menilai dengan surat kabar, keinginan dan gerakannya akan bisa lebih cepat dan meluas sampai ke seluruh perempuan dimanapun ia berada

Surat kabar Sunting Melayu terbit pertama kali tanggal 10 Juli 1912 di Padang dan beredar luas ke seluruh daerah terutama di wilayah Sumatera Barat yang waktu itu lebih dikenal dengan Sumatera Tengah. Surat Kabar ini hasil kerjasama Rohana dengan Dt. St. Maharaja pimpinan surat kabar Utusan Melayu. Rohana bernegosiasi dengan Dt. St. Maharaja melalui korepondensi surat menyurat. Soenting Melayoe hadir dengan tulisantulisan edukasi berkeadilan gender. Di antara tulisan Rohana Kuddus yakni Setia Gerakan 
Perempuan Zaman Ini (SM 23 Mei 1913), Perhiasan Pakaian (SM 7 Agustus 1912), Perempuan (SM 15 Desember 1918), Mencari Isteri (19 Desember 1920) dan seterusnya ${ }^{22}$. Susunan redaksi mulai dari pemimpin redaksi, redaktur, dan penulis semuanya perempuan.

Surat Kabar Sunting Melayu menyoroti segala hal tentang perempuan, isinya berisi syair, tajuk rencana dan karangan yang menggambarkan keistimewaan perempuan. Tulisantulisan didalam sunting melayu pada dasarnya ditujukan untuk menggerakan hati dan pemikiran perempuan. emansipasi dan kesetaraan yang ingin Rohanna capai bukanlah tentang perempuan harus sama seperti laki-laki atau perempuan bisa melebihi laki laki. Tapi melalui salah satu tulisannya rohana menyatakan bahwa laki laki dan perempuan bisa maju bersama. perempuan tidak boleh menyerah, perempuan harus memiliki daya untuk maju, perempuan harus bisa mendapatkan hidup yang lebih baik.

Keputusan Rohanna menerbitkan surat kabar perempuan adalah wujud nyatanya untuk memperbaiki kondisi perempuan Indonesia. Melalui pers, ia ingin menyampaikan kepada masyarakat umum tentang gerakan-gerakan pembebasan perempuan dari keterbelakangan. Rohana ingin mengubah "potret" dan stigma masyarakat tentang perempuan, perempuan adalah makhluk yang independen dan bebas, perempuan bukanlah suatu kelompok yang lemah dan bisa diperlakukan semena-mena, perempuan harus keluar dari keterjajahan, perempuan harus bangkit dari keterbelakangan ilmu pengetahuan dan harus berani mendobrak kontruksi budaya masyarakat yang menempatkan dirinya sebagai kelompok ang terbelakang, terjajah, terkekang, dan termajinalkan. Akibat aksi dan gerakannya yang aktif dalam memprovokasi kebangkitan perempuan dalam mencapai kesetaraan, kehadiran Soenting Melayoe dianggap sebagai surat kabar penentang arus dan sebagai pemberontak otoritas laki- laki yang tidak berpihak pada kesejahteraan perempuan. Atas jasanya Rohanna dalam tulisan-tulisannya tersebut, pemerintah Sumatera Barat menobatkan Rohana sebagai wartawati pertama di Minangkabau, dengan diberikannya penghargaan kepada Rohana Kudus pada tanggal 17 Agustus 1974.

\section{B. Gerakan Politik Rohanna Kuddus Di Minangkabau}

Rohanna kuddus tak hanya dikenal sebagai salah satu pejuang keseteraan perempuan, namun beberapa gerakan-gerakan rohanna diyakini juga memberikan

\footnotetext{
${ }^{22}$ Sari, Susi Ratna. Dari Kerajinan Amai Setia Ke Soenting Melayoe Strategi Rohana Kuddus Dalam Melawan Ketertindasan Perempuan Di Minangkabau . Kafa'ah: Jurnal Ilmiah Kajian Gender. 2016
} 
sumbangsih dalam membangkitkan semangat dan gerakan politik. Rohanna terkenal sering memberikan motivasi dan sumbangsih strategi bagi para pemuda dalam melawan konolinal penjajah. Bahkan tak jarang ucapan-ucapan Rohanna membakar jiwa semangat para pemuda untuk lebih berapi-api dalam melawan kesemena-menaan penjajah.

Rohana pun ikut andil dalam melawan penjajah dalam perang Gerilya dan membantu dapur umum saat terjadinya perang. Serta, melalui tulisan-tulisannya ia juga memainkan peran dalam mengusir penjajah. Melalui tulisan-tulisannya yang acap kali mengkritik dan keras menentang setiap tindakan Belanda yang menyengsarakan masyarakat pribumi. Rohanna menjadi ancaman dan kegelisahan sendiri bagi penjajah. Selaras dengan Sidney Tarrow yang mengatakan Gerakan sosial merupakan politik perlawanan yang terjadi ketika rakyat biasa yang bergabung dengan para kelompok masyarakat yang lebih berpengaruh menggalang kekuatan untuk melawan para elit, pemegang otoritas, dan pihakpihak lawan lainnya. Maka apa yang dilakukan Rohanna adalah salah satu bentuk perlawanan dan gerakan yang dikeluarkan dalam bentuk ide, strategi dan tulisan. Melalui surat kabar dan jalur pers, Rohanna merangkul lebih banyak orang, sehingga dapat lebih leluasa dan memiliki pengaruh dalam menyampaikan ide dan gagasannya melawan pemerintahan kolonial Belanda.

Keberadaan Pers pada zaman penjajahan memberikan peranan penting dan faktor pendorong terbesar untuk menuju pergerakan kemerdekaan. Pers pada masa itu berguna dalam menyebarkan semangat kebangsaan serta ide-ide nasionalisme. Dalam Syarifah Aini dan Rhoma Dwi Aria tentang Soenting Melajoe Newspaper And The Discourse Of Nasionalism, terdapat beberapa wacana wacana nasionalisme yang ditawarkan oleh Surat Kabar Sunting Melayu. Wacana termuat dalam tulisan tulisan para redaktur baik redaktur kelompok laki-laki ataupun perempuan. Wacana nasionalisme Sunting Melayu dalam presprektif Laki-Laki dapat di lihat dari sikap politik yang belum sepenuhnya bersifat anti kolonial, adanya kesamaan identitas yang terdapat dalam Soenting Melajoe tentang kebanggaan dan kecintaan penulis terhadap identitasnya sebagai bangsa Minangkabau dan Hindia Belanda, dan munculnya gerakan memajukan kesejahteraan rakyat. Sementara itu, wacana nasionalisme berdasarkan perspektif perempuan terlihat dari tiga hal yaitu, 
munculnya gerakan emansipasi dan pendidikan bagi perempuan, kemunculan perempuan dalam dunia pers, serta kesadaran membentuk perserikatan perempuan ${ }^{23}$.

Gerakan-gerakan dan tulisan Rohanna mendobrak pemikiran dan semangat pemuda Indonesia lainnya. Rohanna terbukti mampu memberikan pengaruh dalam kebangkitan pemuda. Banyak gerakan-gerakan pemuda yang terinpirasi dari tulisan rohanna. Mulai bermunculannya pergerakan -pergerakan dan perkumpulan perempuan sebagai bentuk kesadaran perempuan terhadap hak dan kewajibannya, misalnya organisasi Serikat Kaoem Iboe Soematera (SKIS) pada tahun1924.

\section{Kesimpulan}

Pantas kiranya sosok Rohanna Kuddus dinobatkan sebagai pahlawan nasional. Sumbangsingnya dalam mencapai kesetaraan perempuan minangkabau tak dapat lagi diragukan. Kepintaran dan kecerdasan yang dimiliki rohana menjadi modal awal rohanna dalam meningkatkan taraf kehidupan perempuan. Rohanna menjadikan pemberdayaan perempuan sebagai satu satunya cara mendobrak keterpinggirkan dan dominasi patriarki yang selama ini membelenggu hidup perempuan. Melalui pendidikan, keterampilan, ekonomi bahkan tulisan Rohanna membongkar paradigma keterjajahan perempuan. Prnsip gender yang ditawarkan rohan tidaklah untuk menunjukan sisi superior wanita, namun Rohanna fokus terhadap bagaimana perempuan bisa mendapat hidup yang lebih baik. Perempuan bisa maju bersama laki-laki. Perempuan berhak mendapat pendidikan, kehidupan ekonomi dan penerimaan publik yang lebih manusiawi, perempuan berhak untuk hidup berkualitas.

Kegencaran rohana memperbaiki kesetaran nasib perempuan, membawa berbagai kebangkitan pemikiran dan gerakan dari kalangan pemuda. Tak hanya laki-laki, bahkan wanita pun mulai aktif bersuara dna menunjukan partisipasinya dalam melawan ketertinggalan dan penindasan akibat praktik penjajah. pikiran pikiran dan semangat Juang rohana menjaid inspirasi lahir dan tumbuhnya perkumpulan perkumpulan dan pergerakan pemuda baru. Yang lebih istimewa, jika sebelumnya perkumpulan pemuda hanya laki laki saja yang bisa dijumpai, namun rohana berhasil merubah kontruksi sosial yang ada.

${ }^{23}$ Aini, Syarifah \& Rhoma Dwi Aria . Soenting Melajoe Newspaper And The Discourse Of Nasionalism (1912-1921). 
Perempuan mulai aktif bersuara dan membentuk perkumpulan-perkumpulan baru baik bersifat untuk kepentingan kelompok, ekonomi sosial ataupun politik.

\section{Daftar Pustaka}

Budi Rajab. Perempuan Dalam Modernisme Dan Postmodernisme. Jurusan Antropologi, Fakultas Ilmu Sosial dan Ilmu Politik, Universitas Padjadjaran.

Etek, Azizah, Mursjid, A.M. \& Arfan, B.R.. (2007). "Koto Gadang Masa Kolonial”, Yogyakarta: LkiS.

Fitriyanti. 2001. Roehana Koeddoes Tokoh Pendidik dan Jurnalis Perempuan Pertama Sumatra Barat. Jakarta : Yayasan Jurnal Perempuan, 2001.

2005. Rohana Kudus. Jakarta: Yayasan D’Nanti

2011. Rohana Kudus, Perempuan Sumatera Barat ( Jakarta : Yayasan Jurnal Perempuan

2013. Perempuan Menguak Dunia. Jakarta : Yayasan d'Nanti,.

Hanani, Silfia, Rohana Kudus dan Pendidikan Perempuan, ( Jurnal : STAIN Syech M. Djamil

Djambek Bukittinggi, 2011).

Kusmayadi, et al., Metodologi Penelitian Dalam Bidang Kepariwisataan (Jakarta: Gramedia Pustaka Utama, 2000), hlm. 28-29. 13Louis Gottschalk, Mengerti Sejarah, terjemahan Nugroho Notosusanto (Jakarta: Universitas Indonesia Press, 1983.

Tamar Djaja. (1980). Rohana Kudus Srikandi Indonesia Riwayat Hidup dan Perjuangannya. Jakarta: Mutiara

Zed, Mestika, dan Hasril Chaniago, (2018), Riwayat Hidup dan Perjuangan Ruhana Kuddus Tokoh Perempuan yang Mendahului Zaman, Padang: UNP Press.

Rohana Kudus, "Pioneer Jurnalis Perempuan \& Pahlawan Nasional dari RanahMinang. Jurnal Humaniora .

Sari, Susi Ratna, Dari Kerajinan Amai Setia hingga Soenting Melayoe Strategi Rohana Kuddus dalam Melawan Ketertindasan Perempuan di Minangkabau, Kafaah: Jurnal Ilmiah Kajian Gender, Vol. VI No. 2 Tahun 2016.

Aini, Syarifah \& Rhoma Dwi Aria . Soenting Melajoe Newspaper And The Discourse Of Nasionalism (1912-1921). 